\title{
PROGRAM PENDAMPINGAN DALAM PENYUSUNAN BAHAN AJAR BERBASIS ECOLITERACY BAGI GURU-GURU SEKOLAH DASAR DI WILAYAH KABUPATEN BANDUNG BARAT
}

(Program Pengabdian Kepada Masyarakat di Kabupaten Bandung barat)

\author{
Hana Sakura Putu Arga1 ${ }^{1}$, Galih Dani Septiyan Rahayu², Ronny Mugara ${ }^{3}$ \\ 1, 2, 3 IKIP SILIWANGI \\ hana-sakura@ikipsiliwangi.ac.id¹, galih040990@ikipsiliwangi.ac.id², \\ ronnymugara@ikipsiliwangi.ac.id ${ }^{3}$
}

\begin{abstract}
ABSTRAK
Program pengabdian kepada masyarakat adalah salah satu bagian dari tridharma perguruan tinggi. Kegiatan pengabdian masyarakat ini dilaksanakan di Kabupaten Bandung barat dengan tujuan jangka panjang program pengabdian ini adalah mengembangkan suatu pembelajaran dengan pendampingan berbasis ecoliteracy di lingkungan Sekolah Dasar (SD). Secara khusus, tujuan yang ingin dicapai sebagai berikut: (1). Meningkatkan pemahaman guru terkait dengan bahan ajar; (2). Meningkatnya pemahaman guru dalam membuat dan mengembangkan bahan ajar berbasis; dan 3). Tersedianya bahan ajar berbasis ecoliteracy di SD. Metode yang akan dipakai dalam upaya pencapaian tujuan tersebut memalui pendampingan yang langkahlangkahnya terdiri dari: (1). mengkaji ecoliteracy; (2). Mempersiapkan bahan-bahan untuk membuat bahan ajar; (3). Melakukan pendampingan bahan ajar berbasis ecoliteracy; (4). Melakukan refleksi dan terkait proses pendampingan; (d). Evaluasi kegiatan pendampingan penyusunan bahan ajar berbasis ecoliteracy. Hasil dari pengabdian ini yaitu tersedianya bahan ajar berbasis ecoliteracy.
\end{abstract}

Kata Kunci : pendampingan, bahan ajar, ecoliteracy

\begin{abstract}
The community service program is one part of the three tri dharma of higher education. This community service activity is carried out in West Bandung Regency with the long-term goal of this community service program is to develop learning with eco-literacy-based assistance in elementary schools. Specifically, the objectives to be achieved are as follows: (1). Improving teacher understanding related to teaching materials; (2). Increased understanding of teachers in making and developing teaching-based materials; and 3). Availability of eco-literacy based teaching materials in elementary schools. The method that will be used in the effort to achieve these goals through assistance that consists of steps: (1). assessing ecoliteracy; (2). Preparing materials for making teaching materials; (3). Assist eco-literacy-based teaching materials; (4). Reflecting and related to the assistance process; (d). Evaluation of mentoring activities on the preparation of eco-literacy-based teaching materials. The result of this dedication is the availability of eco-literacy-based teaching materials.
\end{abstract}

Keywords: mentoring, teaching materials, eco-literacy

\section{A. PENDAHULUAN}

Berdasarkan hasil penelitian dan pengabdian yang telah dilaksanakan sebelumnya oleh (Rahayu, 2018) tentang pengaruh project citizen terhadap kecerdasan ekologis mahasiswa PGSD IKIP Siliwangi, (Arga, 2018) tentang pengaruh project based learning terhadap kecerdasan ekologis pada siswa SD, dan hasil pengabdian yang telah dilaksankan oleh (Rahayu dan Firmansyah, 2018) tentang metode pendampingan dalam 
meningkatkan pemahaman dalam pembelajaran inovatif di SD. Dari beberapa hasil penelitian dan pengabdian tersebut dapat disimpulkan bahwa ecoliteracy atau lebih dikenal dengan kecerdasarn ekologis dapat ditingkatkan dengan berbagai model dan pendampingan dapat memberikan dapak pada berbagai keterampilan dan kemampuan. Akan tetapi dari hasil kajian penelitian dan pengabdian tesebut masih terdapat kesenjangan yaitu belum adanya pengabdian menggunkaan pendampingan dalam penyusunan bahan ajar bertema ecoliteracy pada guru-guru SD. Oleh karena itu, pada pengabdian ini akan melaksanakan pendampingan terhdap guru-guru SD se Kabupaten Bandung Barat dalam dalam meningkatkan pemahaman menyusun bahan ajar di SD.

Hal-hal yang melandasi pengabdian ini adalah sebagai berikut:

1. Berdasarkan data Dapodikdasmen, 2018 jumlah guru sd di Kabupaten bandung barat sangat banyak yaitu sekitar 6.816 guru, akan tetapi masih minim guru yang mengaitkan muatan ekolgi DAS Citarum dalam pembelajaran berupa bahan ajar dan penelitian guru berupa karya tulis PTK.

2. Seperti halnya persoalan yang sekarang ini sedang menjadi perhatian dunia yaitu Sungai Citarum mendapat peringkat ke-3 sungai terkotor sedunia di akhir tahun 2017 dan Tim Survei Kodam III Siliwangi mencatat sebanyak 20.462 ton sampah organik dan anorganik dibuang ke Sungai Citarum.

3. Sekolah di Kabupaten Bandung barat sebagaian besar merupakan sekolah yang berada di aliran DAS Citarum oleh karena itu sudah seharusnya warga yang berada di DAS Citarum turut menjaga dan mebenahi Citarum dan pada hal ini dapat dilakukan oleh guru dan siswa SD melalui pembelajaran di kelasnya.

4. IKIP Siliwangi adalah kampus yang berada di DAS Citarum dan ssudah beberapa tahun kebelakang aktif pada kegiatan membenahi dan melestarikan kawasan sungai citarum khususnya wilayah tengah. Oleh karena itu, para akademisi yaitu dosen dan mahasiswanya mempunyai kewajiban melaksankan pembenahan dan pelestarian melalui pendampingan bagi guru-guru SD di kawasan DAS Citarum. Batasan pengabdian ini adalah sebagai berikut:

1. Pendampingan adalah suatu kegiatan yang dilakukan seseorang yang bersifat konsultatif, interaktif, komunikatif, motivatif, dan negosiatif. 
2. Bahan ajar merupakan salah satu bagian dari sumber ajar yang dapt diartikan sesuatu yang mengandung pesan pembelajaran, baik yang bersifat khusus maupun bersifat umum yang dapat dimanfaatkan untuk kepentingan belajar

3. Ecoliteracy merupakan konsep, paradigma, sekaligus nilai baru yang dimasukan dalam pendidikan menuju "kesejahteraan bumi" yang menggagas gerakan dalam upaya kepedulian terhadap pengetahuan peduli terhadap lingkungan dan bertujuan meningkatkan kesadaran ekologis masyarakat.

\section{B. LANDASAN TEORI}

\section{Pendampingan}

Pendampingan merupakan kegiatan pemberian arahan atau bimbingan pada peserta didik dengan tujuan meningkatkan kemampuan atau kompetensi peserta pelatihan. Kamil (2010) mengemukakan bahwa pendampingan adalah suatu kegiatan yang dilakukan seseorang yang bersifat konsultatif, interaktif, komunikatif, motivatif, dan negosiatif. Pemberian pendampingan kepada peserta pelatihan akan memberikan kemudahan untuk pemahaman materi yang sulit dipahami serta memberikan pendampingan yang lebih terstruktur

\section{Bahan Ajar}

Bahan ajar merupakan salah satu bagian dari sumber ajar yang dapt diartikan sesuatu yang mengandung pesan pembelajaran, baik yang bersifat khusus maupun bersifat umum yang dapat dimanfaatkan untuk kepentingan belajar (Mulyasa, 2006) dan (Rahayu GDS dan Setiyadi R, 2018).

\section{Program Pendampingan Berbasis Kearifan Lokal}

Ecoliteracy sebagai sebuah paradigma baru yang dipopulerkan oleh (Capra, 1995)bersama para praktisi lain baik dari praktisi pendidikan, praktisi lingkungan,dan (Stone dan Barlow, 2005) ecoliteracy merupakan konsep, paradigma, sekaligus nilai baru yang dimasukan dalam pendidikan menuju "kesejahteraan bumi" yang menggagas gerakan dalam upaya kepedulian terhadap pengetahuan peduli terhadap lingkungan dan bertujuan meningkatkan kesadaran ekologis masyarakat.Motivasi Belajar

\section{METODE PELAKSANAAN}

Pelaksanaan program pengabdian kepada masyarakat ini dilaksanakan selama empat bulan mulai dari bulan April-Juli 2019 di Kabupaten Bandung barat. Metdoe 
pelaksanaan pengabdian ini menggunakan metode pendampingan dengan tahap-tahap yaitu: (1) tahap perencanaan, (2) tahap pelaksanaan, (3) tahap evaluasi. Tahap perencanaan telah ditetapkan hal-hal sebagai berikut: tempat/lokasi kegiatan dipilih di kabupaten Bandung barat. Jenis kegiatan berupa pendampingan dalam penyusunan bahan ajar dan karya tulis ilmiah bagi guru-guru SD dengan tema ecoliteracy berbasis muatan ekologi DAS Citarum.

\section{Sosialisasi dan Perijinan}

Sosialisasi dan perijinan merupakan tahap awal kegiatan. Kegiatan ini bertujuan untuk menginformasikan kepada guru-guru SD mengenai sasaran dan rencana kegiatan pengabdian. Kegiatan ini dilakukan dengan metode diskusi langsung dengan pejabat yang berwenang di bidang pendidikan di wilayah yang menjadi lokasi pengabdian.

\section{Persiapan Pendampingan}

Persiapan pendampingan yaitu mempersiapkan bahan-bahan materi penyusunan bahan ajar dan karya tulis ilmiah dengan tema ecoliteracy pada proses pendampingan

\section{Pendampingan}

Pendampingan dilaksanakaan di luar jam sekolah dan dipusatkan di satu lokasi yang strategis sehingga mudah dijangkau oleh guru-guru SD. Materi yang disampaikan dalam kegiatan ini mencakup penyampaian materi mengenai penyusunan bahan ajar dan penyusunan karya tulis ilmiah.

4. Evaluasi proses pendampingan

Evaluasi yang dilakukan dalam kegiatan ini dilaksankan dengan tidak terlalu formal namun tetap dilaksanakan evaluasi terkait pemahaman guru-guru dalam menyusun bahan ajar dan karya tulis ilmiah dengan tema ecoliteracy dengan memanfaatkan muatan ekologi DAS Citarum. Evaluasi menggunakan format wawancara, kuisioner dan dokumentasi

Tahapan pengabdian ini terdiri dari empat tahapan yaitu tahap persiapan, tahap pelaksanaan, tahap penyelesaian, dan tahap publikasi hasil pengabdian. Tahapan penelitian ini berdasarkan hasil penelitian dan pengabdian yang telah di publikasikan pada jurnal penelitian ataupun jurnal pengabdian kepada masyarakat. Adapun secara rinci tahapan-tahapannya adalah sebagai berikut: 


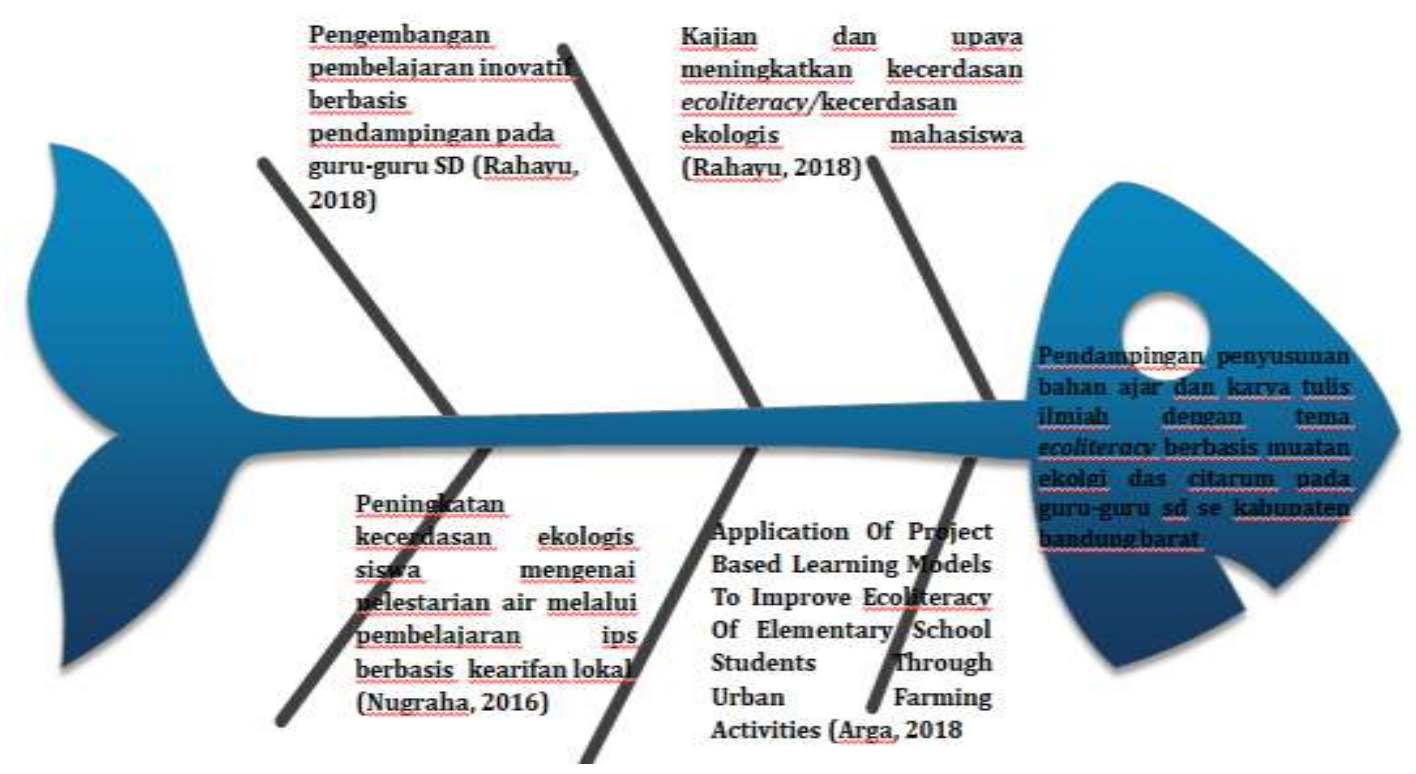

Gambar 1. Roadmap Pengabdian

Subjek pada penelitian ini adalah guru-guru SD se kabupaten Bandung barat yang terdidir dari 16 kecamatan yang dalam pelaksanaannya di sederhanakan masingmasing kecamatan di wakili oleh 5 guru SD sehingga jumlah subjek kegiatan pengabdian ini adalah 80 guru SD.. Lokasi pengabdian dilaksanakan di kabupaten Bandung barat. Adapun proses pendampingan di bagi menjadi beberpa titik sehingga memudahkan dijangkau oleh guru-guru dengan bekerjasama dengan pejabat berwenang dalam bidang pendidikan di wilayah Bandung barat.

\section{HASIL DAN PEMBAHASAN} Hasil

Kegiatan pengabdian masyarakat dilaksanakan di kabupaten Bandung barat dengan subjek pengabdiannya adalah seluruh guru-guru yang ada di Bandung barat dengan sampel pengabdian sebanyak 80 guru SD. Berdasarkan hasil pengabdian kepada masyarakat terkait dengan pendampingan penyusunan bahan ajar berbasis ecoliteracy selama tiga bulan dari mulai bulan Mei-Juli 2019 yaitu diperoleh meningkatnya motivasi guru dalam membuat bahan ajar dan adanya peningkatan jumlah bahan ajar yang disusun oleh guru-guru SD di Kabupaten Bandung barat. Bahan ajar yang tersedia dari kegiatan pendampingan masih berupa draft yaitu media pembelajaran, lembar kerja siswa (LKS), dan alat peraga. Dari 80 guru SD yang mengikuti pendampingan pada kegiatan pembelajaran ini diperoleh data draft bahan ajar sebagai berikut: 


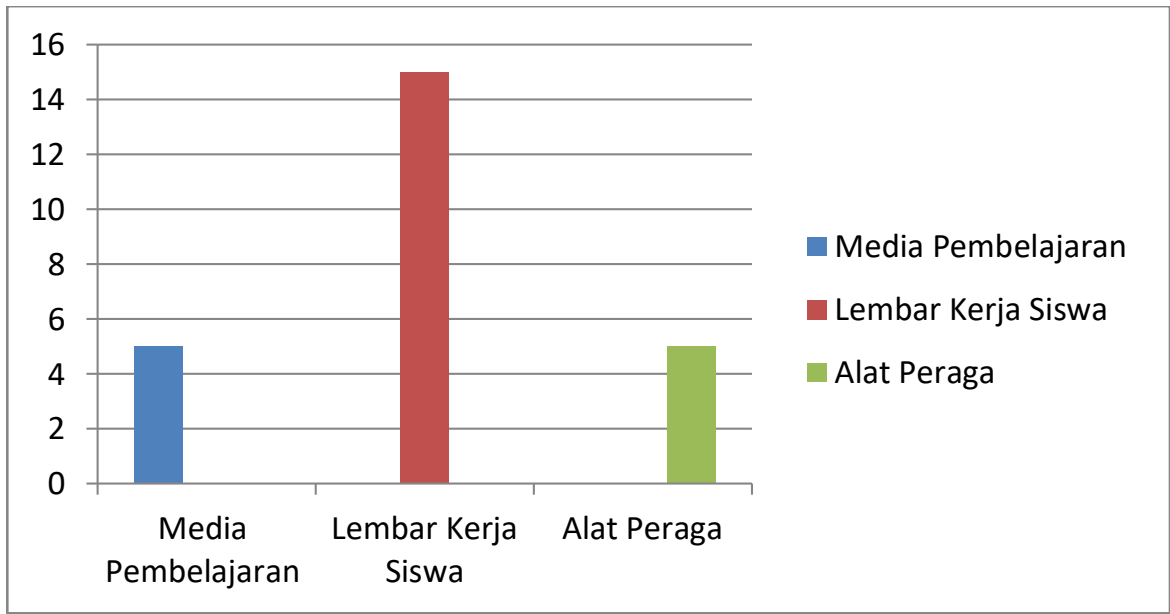

Grafik 1. Daftar Draft Bahan Ajar hasil Pengabdian

Jumlah draft bahan ajar yang dihasilkan dari pengabdian kepada masyarakat ini adalah sebanyak 25 bahan ajar yang berbasis ecoliteracy dengan sebaran jenis seperti pada grafik 1 di atas. Adapun dokumentasi ketika proses pengabdian masyarakat ini adlah sebagai berikut:

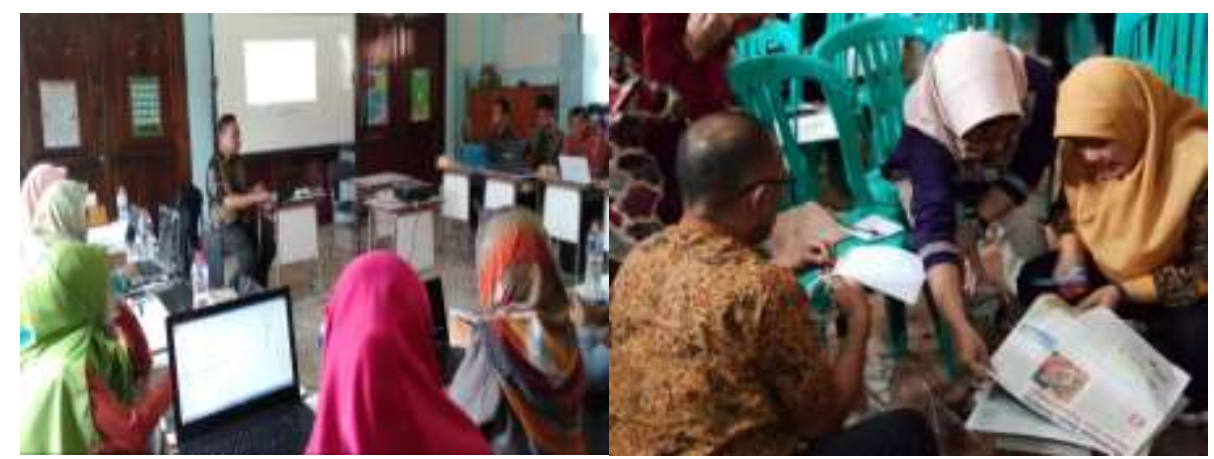

Gambar 2. Kegiatan Pengabdian Kepada Masyarkat

\section{Pembahasan}

Berdasarkan hasil wawancara terhadap peserta kegiatan pengabdian dengan judul pendampingan penyusunan bahan ajar berbasis ecoliteracy terhadap guru-guru SD di wilayah kabupaten Bandung barat yaitu guru-guru merasa terbantu dan temotivasi dalam penyusunan bahan ajar berbasis ecoliteracy.

Dalam proses pendapingan tentunya terdapat berbagai hambatan-hambatan diantaranya terkait dengan waktu pelaksanaan yang dilaksanakan pada siang hari setelah guru melakukan aktivitas mengajar di SD masing-masing sehingga guru terlihat lelah, masih minmalnya pemahaman terkait dengan jenis-jenis bahan ajar sehingga 
membutuhkan waktu yang ekstra dalam proses pendampingan. Hal tersebut dikarenakan guru belum terbiasa menyusun bahan ajar berbasis ecoliteracy.

\section{E. KESIMPULAN}

Berdasarkan hasil pelaksanaan pengabdian pada masyarakat yang telah dilaksanakan di Kabupaten Bandung barat, maka dapat disimpulkan hal-hal sebagai berikut:

1. Kegiatan pengabdian pada masyarakat dapat memberikan manfaat langsung kepada guru-guru SD dalam menyusun bahan ajar berbasis ecoliteracy.

2. Kegiatan pengabdian pada masyarakat ini dapat dijadikan sarana berinovasi dalam usaha mengembangkan pembelajaran/pendampingan dalam meningkatkan kemampuan guru dalam menyusun bahan ajar.

3. Wahana atau laboratorium bagi para dosen dalam mengimplementasikan teori belajar, pengetahuan, dan keterampilan secara nyata, dan bermanfaat bagi masyarakat luas.

\section{F. DAFTAR PUSTAKA}

Arga, H. S. (2018). Aplication Of Project Based Learning Models To Improve Ecoliteracy Of Elementary School Students Through Urban Farming Activities. PrimaryEdu, 95-101.

Capra. (1995). The web of life. New york: Harper Collins.

Mulyasa. (2006). Kurikulum tingkat satuan pendidikan. Bandung: Rosdakarya.

Rahayu dan Firmansyah. (2018). Pengembangan pembelajaran inovatif berbasis pendampingan bagi guru sekolah dasar. Abdimas Siliwangi, 17-25.

Rahayu GDS dan Setiyadi R. (2018). Effect of teaching material Bikin Dongeng Yuk! learning outcomes of class V primary school. PrimaryEdu, 109-116.

Rahayu, G. D. (2018). Penerapan model projec citizen dalam upaya meningkatkan kecerdasan ekologis. Mimbar Sekolah Dasar, 31-42.

Stone dan Barlow. (2005). Ecological literacy: educating our children for a sustaianable world. San Faransisco: Siera club book. 